Jurnal Mitra Pendidikan (JMP Online)

URL : http://e-jurnalmitrapendidikan.com
JMP Online

Vol. 4, No. 12, 794-811.

(C) 2020 Kresna BIP. e-ISSN 2550-0481 p-ISSN 2614-7254

\title{
UPAYA MENINGKATKAN PEMAHAMAN KONSEP MATEMATIKA \\ PADA POKOK BAHASAN HIMPUNAN SISWA KELAS VII D \\ SMP NEGERI 1 BENJENG DENGAN PENERAPAN MODEL \\ PEMBELAJARAN KOOPERATIF TIPE STUDENT TEAMS \\ ACHIEVEMENT DIVISIONS (STAD)
}

\author{
Niswati \\ SMP Negeri 1 Benjeng
}

INFORMASI ARTIKEL

Dikirim : 19 Desember 2020

Revisi pertama : 23 Desember 2020

Diterima : 28 Desember 2020

Tersedia online : 09 Januari 2021

Kata Kunci: Kemampuan Guru,

Pembelajaran Saintifik, Observasi Kelas

Email: niswatiain@gmail.com
ABSTRAK

Penelitian ini bertujuan untuk meningkatkan pemahaman konsep matematika pada pokok bahasan himpunan siswa kelas VII D SMP Negeri 1 Benjeng dengan penerapan model pembelajaran kooperatif tipe Student Teams Achievement Division (STAD) dan untuk mengetahui respons siswa terhadap pembelajaran matematika dengan penerapan model pembelajaran kooperatif tipe STAD.

Jenis penelitian ini adalah Penelitian Tindakan Kelas (PTK) yang dilakukan secara kolaboratif. Partisipan adalah siswa kelas VII D SMP Negeri 1 Benjeng, sebanyak 32 siswa. Tindakan dilaksanakan dalam dua siklus, masing-masing siklus terdiri dari tiga pertemuan. Instrumen yang digunakan untuk mengumpulkan data dalam penelitian ini berupa lembar observasi pelaksanaan pembelajaran matematika dengan penerapan model pembelajaran kooperatif tipe STAD, angket respons siswa, wawancara terhadap siswa dan guru, tes tertulis, catatan lapangan dan dokumentasi.

Hasil penelitian menunjukkan bahwa pembelajaran matematika dengan model pembelajaran kooperatif tipe STAD dapat meningkatkan pemahaman konsep matematika siswa. Hal ini dapat ditunjukkan dengan rata-rata nilai siswa kelas VII D meningkat dari tes kemampuan awal sebesar 50,67 ke siklus I sebesar 71,76, dan siklus II sebesar 75,56. Sedangkan ketuntasan belajar siswa pada siklus I sebesar 72,73\%, dan pada siklus II meningkat menjadi $87,5 \%$ maka telah memenuhi kriteria ketuntasan minimal pada pokok bahasan Himpunan. Berdasarkan angket respons siswa terhadap pembelajaran matematika menggunakan STAD, menunjukkan respon sangat baik dengan rata-rata persentase sebesar $83,98 \%$. 


\section{PENDAHULUAN \\ Latar Belakang}

Matematika adalah mata pelajaran yang diajarkan mulai dari tingkat SD sampai sekolah tingkat menengah dan perguruan tinggi. Sampai saat ini matematika masih dianggap mata pelajaran yang sulit, membosankan, bahkan menakutkan. Anggapan ini mungkin tidak berlebihan selain mempunyai sifat yang abstrak, matematika juga memerlukan pemahaman konsep yang baik, karena untuk memahami konsep yang baru diperlukan prasyarat pemahaman konsep sebelumnya.

Menurut Anas Sudijono (1996: 50) pemahaman adalah kemampuan seseorang untuk mengerti atau memahami sesuatu setelah sesuatu itu diketahui dan diingat. Seorang peserta didik dikatakan memahami sesuatu apabila ia dapat memberikan penjelasan atau memberi uraian yang lebih rinci tentang hal itu dengan menggunakan kata-katanya sendiri.

Dalam mempelajari matematika, pemahaman konsep matematika sangat penting untuk siswa. Karena konsep matematika yang satu dengan yang lain berkaitan sehingga untuk mempelajarinya harus runtut dan berkesinambungan. Jika siswa telah memahami konsep-konsep matematika maka akan memudahkan siswa dalam mempelajari konsep-konsep matematika berikutnya yang lebih kompleks. Dalam laporan hasil belajar siswa aspek-aspek yang dilaporkan kepada orang tua siswa tentang hasil belajar siswa adalah (1) pemahaman konsep, (2) penalaran dan komunikasi, (3) pemecahan masalah. Berarti pemahaman konsep disini sangat diperlukan untuk mengetahui sejauh mana siswa menguasai materi yang telah diajarkan. Pemahaman konsep tersebut perlu ditanamkan kepada peserta didik sejak dini yaitu sejak anak tersebut masih duduk dibangku sekolah dasar maupun bagi siswa Sekolah Lanjutan Tingkat Pertama. Disana mereka dituntut mengerti tentang definisi, pengertian, cara pemecahan masalah maupun pengoperasian matematika secara benar, karena akan menjadi bekal dalam mempelajari matematika pada jenjang pendidikan yang lebih tinggi.

Berdasarkan hasil observasi yang peneliti lakukan di SMP Negeri 1 Benjeng khususnya kelas VII D, diketahui bahwa pembelajaran matematika yang dilakukan lebih terpusat pada guru, sementara siswa cenderung pasif. Hampir sebagian besar siswa justru mengaku bahwa mereka seringkali masih mengalami kesulitan untuk memahami pokok bahasan matematika yang dijelaskan oleh guru. Sebagian siswa hanya menghafal rumus tanpa mengetahui alur penyelesaian atau rumus awal yang dijadikan dasar dari permasalahan yang diberikan. Terlebih lagi jika mereka diberikan soal dengan sedikit variasi yang membutuhkan penalaran lebih.Hanya beberapa siswa yang mampu menjawab dengan benar, itu pun siswasiswi yang memang tergolong lebih pandai dari siswa-siswi yang lain di kelasnya. Selain itu, banyak juga siswa yang mengaku bahwa ketika guru menjelaskan suatu pokok bahasan yang baru, terkadang mereka lupa akan inti dari pokok bahasan yang telah dijelaskan pada pertemuan-pertemuan sebelumnya. Beberapa kejadian yang telah dijelaskan tersebut menunjukkan bahwa pemahaman konsep matematika siswa masih rendah.

Berdasarkan informasi dari guru matematika di SMP Negeri 1 Benjeng menyatakan bahwa sebagian siswa memiliki pemahaman konsep matematika yang 
kurang, hal ini terlihat pada sebagian besar materi yang diajarkan dalam matematika tidak terkecuali pokok bahasan himpunan. Saat pembelajaran berlangsung siswa tidak berani untuk menanyakan kesulitan dalam memahami materi maupun dalam mengerjakan soal yang diberikan guru. Inisiatif siswa kurang, hal tersebut terlihat ketika guru memberi kesempatan siswa untuk bertanya maupun berpendapat tidak dimanfaatkan dengan baik oleh siswa.

Model pembelajaran kooperatif adalah model pembelajaran yang lebih mengedepankan siswa pada kerja dalam kelompok belajar. Dalam pembelajaran kooperatif siswa belajar dalam kelompok-kelompok kecil. Ada beberapa model dalam pembelajaran kooperatif salah satu diantaranya adalah model pembelajaran kooperatif tipe Student Teams Achievement Division (STAD). Dengan kondisi siswa yang kurang mampu dalam memahami konsep matematika, maka kooperatif STAD ini diharapkan mampu meningkatkan semangat siswa dalam memahami konsep matematika dan dapat mempermudah siswa belajar matematika, sehingga dapat meningkatkan pemahaman konsep matematika siswa.

Strategi yang paling sering digunakan untuk mengaktifkan siswa adalah melibatkan siswa dalam kerja kelompok, maka sangat sesuai dengan model pembelajaran kooperatif tipe STAD. Dengan demikian memungkinkan terciptanya suasana belajar yang menyenangkan bagi siswa, menumbuhkan rasa kepemilikan siswa terhadap kegiatan pembelajaran, meningkatkan interaksi dan kerjasama diantara siswa untuk bersama-sama meningkatkan hasil belajar, meningkatkan komunikasi dan interaksi dengan guru dan menciptakan situasi pembelajaran yang kondusif. Dengan berdiskusi siswa dapat berfikir kritis, saling menyampaikan pendapat, saling memberi kesempatan menyalurkan kemampuan, saling membantu belajar, saling menilai kemampuan dan peranan diri sendiri maupun teman lain, mengekspresikan dirinya secara bebas, menyumbangkan pikirannya untuk memecahkan masalah bersama. Termasuk belajar dalam kelompok adalah membandingkan jawaban dan meluruskan jika ada anggota kelompok yang mengalami kesalahan konsep. Dengan demikian dapat meningkatkan pemahaman konsep matematika siswa.

Berdasarkan analisis situasi pembelajaran matematika di SMP Negeri 1 Benjeng peneliti bekerja sama dengan guru matematika SMP Negeri 1 Benjeng berupaya untuk mencari penyelesaian dalam pembelajaran matematika dengan menerapkan model pembelajaran kooperatif tipe STAD sebagai upaya peningkatan pemahaman konsep matematika siswa, karena model pembelajaran kooperatif tipe STAD belum pernah dilaksanakan di kelas VII D SMP Negeri 1 Benjeng. Dengan demikian diharapkan pemahaman konsep matematika siswa meningkat.

\section{Rumusan Masalah}

Berdasarkan uraian di atas, penulis dapat mengemukakan rumusan masalah dalam penelitian ini adalah apakah penerapan model pembelajaran kooperatif tipe Student Teams Achievement Division (STAD) yang dapat meningkatkan pemahaman konsep matematika siswa pada pokok bahasan himpunan di kelas VII D SMP Negeri 1 Benjeng?” 


\section{Tujuan Penelitian}

Tujuan yang ingin dicapai dalam penelitian ini adalah untuk mendiskripsikan pelaksanaan pembelajaran kooperatif tipe Student Teams Achievement Division (STAD) sebagai upaya untuk meningkatka pemahaman konsep matematika siswa pada pokok bahasan himpunan kelas VII D SMP Negeri 1 Benjeng

\section{KAJIAN PUSTAKA Pembelajaran Matematika}

Pembelajaran adalah upaya untuk menciptakan iklim dan pelayanan terhadap kemampuan, potensi, minat, bakat dan kebutuhan peserta didik yang beragam agar terjadi interaksi optimal antara guru dengan siswa serta antara siswa dengan siswa Menurut Saiful Sagala (2009: 61) pembelajaran ialah membelajarkan siswa menggunakan asas pendidikan maupun teori belajar merupakan penentu utama keberhasilan pendidikan. Pembelajaran merupakan proses komunikasi dua arah, mengajar dilakukan oleh guru sebagai pendidik, sedangkan belajar dilakukan oleh peserta didik atau murid.

Dalam pembelajaran matematika salah satu upaya yang dilakukan oleh guru adalah dengan menggunakan model pembelajaran Kooperatif tipe STAD karena dengan menggunakan model pembelajaran ini dapat terjadi proses saling membantu diantara anggota-anggota kelompok untuk memahami konsep-konsep matematika dan memecahkan masalah matematika dengan kelompoknya.

Dari uraian di atas dapat disimpulkan bahwa pembelajaran matematika adalah suatu upaya penataan lingkungan belajar siswa tentang konsep-konsep dan struktur-struktur yang terdapat dalam matematika yang pada akhirnya siswa dapat mengkomunikasikan konsep-konsep dan struktur-struktur tersebut sehingga proses belajar dapat berkembang secara optimal.

\section{Pembelajaran Kooperatif}

Slavin (2005: 4) mengemukakan bahwa pembelajaran kooperatif adalah berbagai macam metode pembelajaran di mana para siswa bekerja dalam kelompok-kelompok kecil yang memiliki tingkat kemampuan yang berbeda untuk saling membantu satu sama lainnya dalam mempelajari materi pelajaran. Dalam kelas kooperatif, siswa diharapkan dapat saling membantu, saling mendiskusikan dan berargumentasi, untuk mengasah pengetahuan yang mereka kuasai saat itu dan menutup kesenjangan dalam pemahaman masing-masing. Dalam menyelesaikan tugas kelompok, setiap anggota saling bekerja sama dan membantu memahami suatu bahan pelajaran artinya bahan belum selesai jika salah satu teman dalam sekelompok belum menguasai bahan pembelajaran.

Sedangkan Erman Suherman, dkk (2003: 260) menyebutkan bahwa pembelajaran kooperatif merupakan suatu kelompok siswa yang bekerja sebagai sebuah tim untuk menyelesaikan sebuah masalah, menyelesaikan tugas atau mengerjakan sesuatu untuk mencapai tujuan bersama. Siswa dalam kelompok tidak menyelesaikan masalah secara sendiri-sendiri dan tidak juga menyelesaikan hanya salah satu orang di antara mereka. 
Pembelajaran kooperatif pada dasarnya merupakan model pembelajaran yang sistematis dengan mengelompokkan siswa untuk melakukan pembelajaran yang efektif agar siswa dapat memaksimalkan kegiatan belajar, dimana keberhasilan individu diorientasikan dalam keberhasilan kelompok. Dalam hal ini siswa bekerjasama belajar dalam kelompok serta bertanggungjawab pula terhadap kegiatan belajar siswa lain dalam kelompoknya untuk melakukan usaha yang sama, bekerja seperti yang ia lakukan.

\section{Pembelajaran Kooperatif Tipe Student Team Achievement Division (STAD)}

STAD merupakan salah satu model pembelajaran kooperatif yang paling sederhana. Sehingga model pembelajaran ini dapat digunakan oleh guru-guru yang baru memulai menggunakan pendekatan pembelajaran kooperatif (Slavin, 2008:143).

STAD dikembangkan oleh Robert E.Slavin dan teman- temannya di Universitas John Hopkin. Dalam STAD, para siswa dibagi dalam tim belajar yang terdiri atas empat orang yang berbeda beda tingkat kemampuan, jenis kelamin, dan latar belakang etniknya. Guru menyampaikan pelajaran, lalu siswa bekerja dalam tim mereka untuk memastikan bawa semua anggota tim telah menguasai pelajaran. Selanjutnya, semua siswa mengerjakan kuis mengenai materi secara sendirisendiri, di mana saat itu mereka tidak diperbolehkan untuk saling membantu (Slavin, 2008: 11-13)

Skor kuis para siswa dibandingkan dengan rata-rata pencapaian mereka sebelumnya, dan kepada masing-masing tim akan diberikan point berdasarkan tingkat kemajuan yang diraih siswa dibandingkan hasil yang mereka capai sebelumnya. Poin ini kemudian dijumlahkan untuk memperoleh skor tim, dan tim yang berhasil memenuhi kriteria tertentu akan mendapatkan penghargaan. Seluruh rangkaian kegiatan, termasuk persentasi yang disampaikan oleh guru, praktik tim, dan kuis biasanya memerlukan waktu 3-5 periode kelas.

STAD telah digunakan dalam berbagai mata pelajaran, salah satunya adalah pelajaran matematika. Gagasan utama dari STAD adalah untuk meningkatkan pemahaman konsep siswa supaya dapat saling mendukung dan membantu satu sama lain dalam menguasai materi yang diajarkan oleh guru. Jika para siswa ingin agar timnya mendapatkan penghargaan tim, mereka harus membantu teman satu timnya untuk mempelajari materi. Mereka harus mendukung teman satu timnya untuk bisa melakukan yang terbaik, menunjukkan bahwa belajar itu penting, berharga dan menyenangkan. Para siswa bekerjasama setelah guru menyampaikan materi pelajaran. Mereka boleh mendiskusikan dari pendekatan penyelesaian masalah, atau mereka juga boleh saling memberikan kuis mengenai objek yang mereka pelajari.Mereka saling bekerjasama dengan teman satu timnya, menilai kekuatan dan kelemahan untuk membantu mereka berhasil dalam kuis.

Pembelajaran kooperatif tipe Student Team Achievement Division (STAD) terdiri atas lima komponen utama, yaitu persentasi kelas, tim, kuis, skor peningkatan individual dan penghargaan tim (Slavin, 2008: 143-163). Pada persentasi kelas, materi dalam STAD pertama-tama diperkenalkan terlebih dahulu. Ini merupakan pengajaran langsung seperti yang sering kali dilakukan atau 
didiskusikan pelajaran yang dipimpin oleh guru. Pada persentasi kelas ini haruslah benar berfokus pada unit STAD. Dengan cara ini, para siswa akan menyadari bahwa mereka harus benar-benar memberi perhatian penuh selama persentasi kelas, karena dengan demikian akan sangat membantu mereka mengerjakan kuiskuis, dan skor kuis mereka menenentukan skor timnya.

Tim terdiri atas empat atau lima siswa yang mewakili seluruh bagian dari kelas dalam hal akademik dan jenis kelamin. Fungi utama dari tim ini adalah memastikan bahwa semua anggota tim benar-benar belajar, dan lebih khususnya lagi adalah untuk mempersiapkan anggotanya untuk mengerjakan kuis dengan baik.

Kuis diberikan setelah tahap persentasi dan praktik tim telah selesai. Para siswa tidak boleh saling membantu selama mengerjakan kuis. Skor kemajuan individual adalah untuk memberikan kepada siswa tujuan kinerja yang akan dapat dicapai apabila mereka bekerja lebih giat dan memberikan kinerja yang lebih baik daripada sebelumnya. Tiap siswa dapat memberikan kontribusi poin yang maksimal kepada timnya dalam sistem skorini.

\section{METODE PENELITIAN Jenis Penelitian}

Jenis penelitian ini adalah Penelitian Tindakan Kelas (PTK) yang dilakukan secara kolaboratif antara peneliti dengan guru matematika kelas VII D SMP Negeri 1 Benjeng. Pada tahap awal guru dan peneliti mendiskripsikan permasalahan penelitian dan menentukan rencana tindakan. Rencana tindakan yang telah disusun bersama, kemudian dipraktikan oleh guru saat melakukan pembelajaran di kelas. Pada saat guru melakukan pembelajaran, peneliti berada di kelas yang sama dan mencatat segala sesuatu yang terjadi saat pembelajaran

\section{Tempat, Waktu dan Subjek Penelitian}

Penelitian ini dilaksnakan di kelas VII D SMP Negeri 1 Benjeng, yang terletak di Jalan Dermo No.05 Desa Dermo Kecamatan Benjeng Kabupaten Gresik, pengambilan data penilitian ini akan dilaksanakan pada bulan Oktober 2016 dengan menyesuaikan jam pelajaran matematika di SMP Negeri 1 Benjeng. Subyek penelitian ini adalah siswa-siswi kelas VII D SMP Negeri 1 Benjeng.

\section{Teknik Pengumpulan Data}

Data dikumpulkan dalam penelitian ini dilakukan melalui beberapa teknik yang dapat dijelaskan sebagai berikut:

\section{Teknik Observasi}

Teknik observasi digunakan untuk memperoleh data langsung dari pelaksanaan aktivitas kegiatan yang sudah direncanakan berupa data nilai observasi pelaksanaan pembelajaran dengan teknik observasi kelas pada 7 Guru TK Binaan Kabupaten Lumajang. Berikut merupakan bentuk instrument pembelajaran saintifik meliputi :

2. Teknik Dokumentasi

Teknik dokumentasi digunakan untuk memperoleh berbagai dokumen yang berupa data nama guru, nama observer, dan jadwal kegiatan pelatihan 
Supervisi Akademik untuk memperkuat perolehan data dari teknik observasi dan teknik wawancara.

\section{Teknik Analisis Data}

Teknis analisis data yang digunakan adalah analisis data penelitian deskriptif kuantitatif, Suharsimi Arikunto (2010:282) data kuantitatif berupa angka-angka. Data yang sudah terkumpul melalui beberapa teknik pengumpul data, data kuantitatif diperoleh dari tabulasi kemudian dianalisis dengan cara mendeskripsikan data, data yang dimaksud yakni data nilai pelaksanaan pembelajaran saintifik.

Penentuan pemberian nilai adalah berdasarkan kualitas pelaksanaan pembelajaran saintifik. Dengan nilai 1 untuk guru dengan pelaksanaan pembelajaran saintifik.yang tidak berkualitas. Perolehan nilai 2 untuk untuk guru dengan pelaksanaan pembelajaran saintifik yang kurang berkualitas. Perolehan nilai 3 untuk untuk guru dengan pelaksanaan pembelajaran saintifik yang berkualitas dan perolehan nilai 4 untuk guru dengan pelaksanaan pembelajaran saintifik yang sangat berkualitas. Adapun tabel penjelasan mengenai kriteria penilaian adalah sebagai berikut:

Tabel 1. Kriteria Penilaian

\begin{tabular}{|c|c|}
\hline Skor 1 & Tidak Berkualitas \\
\hline Skor 2 & Kurang Berkualitas \\
\hline Skor 3 & Berkualitas \\
\hline Skor 4 & Sangat Berkualitas \\
\hline
\end{tabular}

Sumber : Data Primer (2016)

Data yang sudah terkumpul melalui data nilai observasi kemudian dianalisis dengan cara mendeskripsikan data nilai observasi kualitas pelaksanaan pembelajaran saintifik, yaitu sebagai berikut :
Nilai
$=$
$\sum$ Nilai Riil $x 100 \%$
$\sum$ Nilai Ideal
Rata-rata $=\sum \frac{\text { Jumlah Total Nilai }}{\sum \text { Jumlah Kelas }} \times 100 \%$

Berdasaarkan analisis data tersebut kemudian didapatkan nilai yang menjadi hasil akhir rata-rata dari nilai observasi setiap kelas kemudian dapat dikelompokkan berdasarkan tabel sebagai berikut:

Tabel 2. Kategori Penilaian

\begin{tabular}{|c|c|}
\hline Skor 1 & $81-100 \%$ \\
\hline Skor 2 & $61-80 \%$ \\
\hline Skor 3 & $41-60 \%$ \\
\hline Skor 4 & $\leq 40 \%$ \\
\hline
\end{tabular}

Sumber : Data Primer (2016)

Berdasarkan tabel tersebut dapat dijelaskan bahwa rata-rata nilai yang kurang dari $60 \%$ berada dalam kategori kurang. Rata-rata nilai antara $61-74 \%$ berada dalam kategori cukup. Rata-rata nilai antara 75-89\% berada dalam kategori baik. Rata-rata nilai antara $90-100 \%$ berada dalam kategori sangat baik.

Analisis data yang dilakukan dalam penilaian kualitas pelaksanaan pembelajaran saintifik dan penentuan kategori dilakukan untuk setiap siklus. 


\section{HASIL PENELITIAN DAN PEMBAHASAN Hasil Penelitian Siklus I}

Pada siklus I, dilaksanakan pertemuan sebanyak 3 kali pertemuan, dimana pertemuan pertama dan kedua dengan alokasi waktu masing- masing 2 x 40 menit untuk materi dan pertemuan ketiga dengan alokasi waktu 1 x 40 menit untuk tes. Materi yang dipersiapkan untuk siklus I adalah himpunan bagian serta irisan dan gabungan himpunan. Disediakan 2 buah LKS dan Kuis untuk pertemuan pertama dan kedua sesuai dengan materi yang akan diajarkan dan 1 buah soal tes untuk pertemuan ketiga.

a. Data Hasil Observasi

Observasi dilakukan untuk mengetahui sejauh mana keterlaksanaan pembelajaran matematika dengan menggunakan model pembelajaran kooperatif tipe Student Team Achievement Divisions (STAD). Observasi dilakukan oleh peneliti dan satu pengamat independent.

Berdasarkan hasil observasi pembelajaran sudah baik, hal ini dapat terlihat dalam lembar observasi bahwa semua tahapan dalam STAD sudah terlaksana, meskipun ada beberapa siswa yang bercanda dan masih ada siswa yang memanfaatkan waktu diskusi untuk berbincang-bincang di luar materi pelajaran sehingga pembelajaran menjadi kurang optimal. Selain itu ketika guru bertanya kepada siswa tentang himpunan semesta dan himpunan kosong ada beberapa siswa nampak bingung dan hanya beberapa orang siswa saja yang dapat menjawab dengan benar. Hal ini menunjukkan bahwa pelajaran yang telah lalu sudah dilupakan oleh siswa dan siswa tidak belajar terlebih dahulu sebelum pembelajaran mulai.

b. Data Hasil Tes

Tes tertulis pada siklus I terdiri dari kuis I, kuis II dan tes akhir siklus I. Tes ini bertujuan untuk mengukur peningkatan pemahaman konsep matematika siswa. Untuk lebih jelasnya hasil dari kuis I, kuis II, dan tes akhir pada siklus I dalam grafik berikut.

Gambar 1. Grafik Hasil Belajar Matematika Siswa Kuis I, Kuis II dan Tes Akhir Siklus I

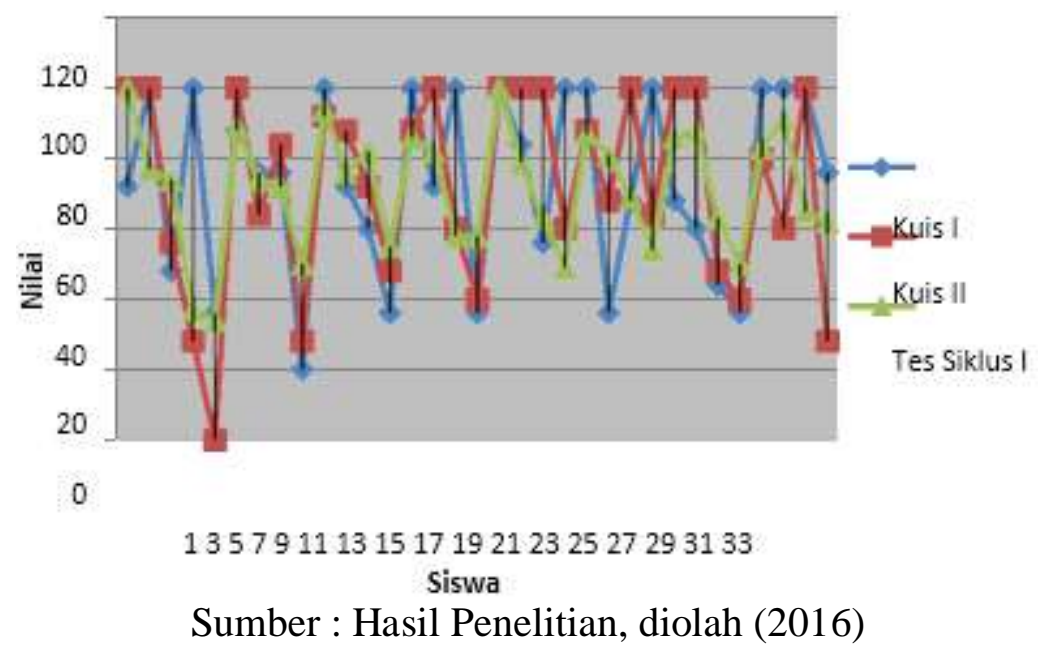


Berdasarkan hasil kuis I nilai rata-rata siswa adalah 73,33 dengan nilai terendah 20 dan nilai tertinggi 100. Nilai rata-rata siswa meningkat pada kuis II menjadi 74.5, dengan nilai terendah 28 dan nilai tertinggi 100.

Pada akhir siklus dilaksanakan tes akhir siklus I, diikuti oleh 33 siswa. Tes akhir siklus I mengalami penngkatan darisiklus awal. Berdasarkan hasil tes siklus I, nilai rata-rata siswa adalah 71,76 meningkat dari tes awal yang rataratanya hanya 50,67. Dengan rata- rata persentase skor jawaban benar siswa pada siklus I adalah $72,11 \%$ berada pada kriteria tinggi. Nilai terendah 34 dan nilai tertinggi 100 . Sebanyak 24 siswa atau $72,73 \%$ yang mencapai nilai lebih dari atau sama dengan 60.

Hasil analisis kemampuan pemahaman konsep matematika siswa menunjukkan kemampuan siswa dalam menyatakan ulang sebuah konsep masuk dalam kategori tinggi dengan persentase skor jawaban benar siswa sebesar $84,85 \%$. Kemampuan untuk mengklasifikasikan obyek-obyek menurut sifat-sifat tertentu (sesuai dengan konsepnya) masih masuk dalam kategori cukup dengan persentase skor jawaban benar siswa sebesar 67,73\%. Kemampuan siswa dalam memberi contoh dan non contoh dari konsep masih masuk dalam kategori cukup dengan persentase skor jawaban benar siswa sebesar $66,41 \%$. Kemampuan siswa dalam menyajikan konsep dalam berbagai bentuk representasi matematis sudah masuk dalam kategori tinggi dengan persentase skor jawaban benar siswa sebesar 77,27\%. Kemampuan siswa dalam mengembangkan syarat perlu dan syarat cukup suatu konsep masih masuk dalam kategori cukup dengan persentase skor jawaban benar siswa sebesar $69,05 \%$. Kemampuan siswa dalam menggunakan, memanfaatkan, dan memilih prosedur atau operasi tertentu sudah masuk dalam kategori tinggi dengan persentase skor jawaban benar siswa sebesar 70,45\%, Kemampuan siswa dalam mengaplikasikan konsep atau algoritma pemecahan masalah masih masuk dalam kategori cukup dengan persentase skor jawaban benar siswa sebesar $68,98 \%$.

Rata-rata kelas pada saat kuis I dan kuis II lebih tinggi dibandingkan nilai rata-rata tes akhir siklus I ini dikarenakan kuis diadakan langsung setelah pembelajaran berlangsung jadi siswa masih ingat dengan pelajaran yang disampaikan.

c. Refleksi

Berdasar hasil tes siklus I dapat dilihat bahwa nilai rata-rata siswa adalah 71,76, hal ini telah terjadi peningkatan dari tes awal dengan nilai ratarata siswa 50,67. Persentase ketuntasan belajar siswa juga telah memenuhi kriteria ketuntasan minimal yaitu 72,73\%. Akan tetapi, dalam analisis hasil tes siklus I masih ada indikator pemahaman konsep yang masih berada dalam kriteria cukup yaitu mengklasifikasikan obyek-obyek menurut sifat-sifat tertentu (sesuai dengan konsepnya), memberi contoh dan non-contoh dari konsep, mengembangkan syarat perlu atau syarat cukup suatu konsep, mengaplikasikan konsep atau algoritma pemecahan masalah.

Hal ini dikarenakan selama siklus I pelaksanaan pembelajaran yang telah dilakukan mengalami kekurangan dan hambatan, antara lain: 
1. Siswa sering menggunakan kesempatan diskusi untuk bercanda dengan teman, sehingga mereka tidak dapat menyelesaikan tugas tepatwaktu.

2. Kerja sama dalam kelompok kurang ini dapat terlihat saat diskusi kelompok. Hanya sebagian siswa dalam satu kelompok yang mengerjakan dan sebagian siswa hanya mengikuti hasil jawaban yang diperolehtemanya.

\section{Siklus II}

\section{a. Data Hasil Observasi}

Observasi dilakukan untuk mengetahui sejauh mana keterlaksanaan pembelajaran matematika dengan model pembelajaran kooperatif tipe Student Team Achievement Divisions (STAD). Observasi dilakukan oleh peneliti dan satu pengamatindependent.

Berdasarkan hasil observasi, pembelajaran sudah terlaksana dengan baik dan lancar. Guru memeriksa kesiapan siswa dan menyampaikan tujuan pembelajaran. Setiap saat guru memberikan motivasi kepada siswa untuk berperan aktif dan bekerjasama dengan kelompok masing-masing. Sehingga diskusi dalam kelompok terlaksana dengan baik, siswa lebih aktif dibandingkan dengan pertemuan-pertemuan sebelumnya. Selain itu, selama proses pembelajaran guru juga memotivasi siswa untuk berani bertanya tentang hal-hal yang mereka belum mengerti, meminta siswa untuk teliti dalam mengerjakan soal. Siswapun mulai tidak segan untuk bertanya padaguru.

Guru memantau jalannya diskusi dan presentasi, di akhir pembelajaran guru juga tidak lupa untuk menegaskan kembali materi yang dipelajari hari ini. Dengan demikian kegiatan pembelajaran matematika dengan menggunakan model STAD berjalan dengan baik dan membuat kegiatan belajar menjadi lebih terarah.

\section{b. Data Hasil Tes}

Hasil tes terdiri dari hasil kuis yang dilakukan pada akhir pembelajaran, yaitu kuis III dan kuis IV dan nilai tes akhir siklus II. Rata-rata nilai kuis III yang diperoleh siswa 89,38 dengan nilai terendah 48 dan nilai tertinggi 100 . Sedangkan kuis IV diperoleh nilai rata-rata siswa 88,79 dengan nilai terendah 50 dan nilai tertinggi100.

Tes akhir siklus II mengalami penngkatan darisiklus I. Hal tersebut ditandai dengan nilai rata-rata siswa pada siklus I 71,76, pada siklus II menjadi 75,56 dengan nilai terendah 39 dan nilai tertinggi 98. Pada siklus I, banyaknya siswa yang mencapai KKM sebanyak 24 siswa atau 72,73\%, pada siklus II sebanyak 28 siswa atau $87,5 \%$. Persentase rata-rata skor jawaban benar siswa pada siklus II berada pada kriteria tinggi. Berikut disajikan grafik hasil kuis III, kuis IV dan tes akhir siklus II. 


\section{Gambar 2. Grafik Hasil Belajar Matematika Siswa Kuis III, Kuis IV dan Akhir Siklus II}

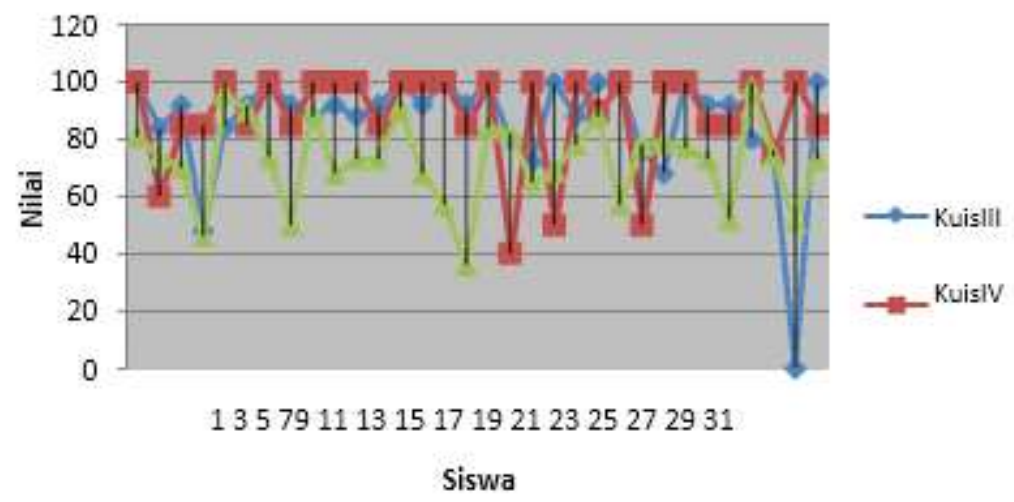

Sumber : Hasil Penelitian, diolah (2016)

Hasil analisis kemampuan pemahaman konsep matematika siswa, menunjukkan kemampuan siswa dalam menyatakan ulang sebuah konsep dari siklus II mengalami peningkatan, pada siklus I presentase skor jawaban benar siswa masuk dalam kategori tinggi, sedangkan pada siklus II masuk dalam kategori sangat tinggi dengan persentase skor jawaban benar siswa sebesar $85,62 \%$. Kemampuan untuk mengklasifikasikan obyek-obyek menurut sifatsifat tertentu (sesuai dengan konsepnya) pada siklus I masih masuk dalam kategori cukup, sedangkan pada siklus II masuk dalam kategori tinggi dengan persentase skor jawaban benar siswa sebesar 70,31\%. Kemampuan siswa dalam memberi contoh dan non contoh dari konsep pada siklus I masih masuk dalam kategori cukup, sedangkan pada siklus II masuk dalam kategori tinggi dengan persentase skor jawaban benar siswa sebesar 71,09\%. Kemampuan siswa dalam menyajikan konsep dalam berbagai bentuk representasi matematis pada siklus I sudah masuk dalam kategori tinggi, sedangkan pada siklus II masuk dalam kategori sangat tinggi dengan persentase skor jawaban benar siswa sebesar $86,25 \%$. Kemampuan siswa dalam mengembangkan syarat perlu dan syarat cukup suatu konsep pada siklus I masih masuk dalam kategori cukup, sedangkan pada siklus II masuk ke salam kategori tinggi dengan persentase skor jawaban benar siswa sebesar $72.66 \%$. Kemampuan siswa dalam menggunakan, memanfaatkan, dan memilih prosedur atau operasi tertentu pada siklus II sama seperti pada siklus I sudah masuk dalam kategori tinggi dengan presentase skor jawaban benar siswa sebesar 74,22\%. Kemampuan siswa dalam mengaplikasikan konsep atau algoritma pemecahan masalah pada siklus I masih masuk dalam kategori cukup, sedangkan pada siklus II masuk dalam kategori tinggi dengan persentase skor jawaban benar siswa sebesar 70,45\%.

c. Data Hasil Angket Respon Siswa

Angket respon siswa diberikan untuk mengetahui respon siswa terhadap pembelajaran matematika dengan model pembelajaran kooperatif tipe. Student Team Achievement divisions (STAD). Angket respon siswa diberikan pada akhir siklus II. Hasil angket respon siswa menunjukkan bahwa persentase respon siswa-siswa terhadap pembelajaran matematika dengan model pembelajaran kooperatif tipe Student Team Achievement Divisions (STAD) adalah $83,98 \%$ dan termasuk ke dalam kategori kriteria sangat baik. Untuk 
lebih jelas persentase respon siswa di setiap aspeknya pada diagram batang berikut ini.

\section{Gambar 3. Presentase Respon Siswa}

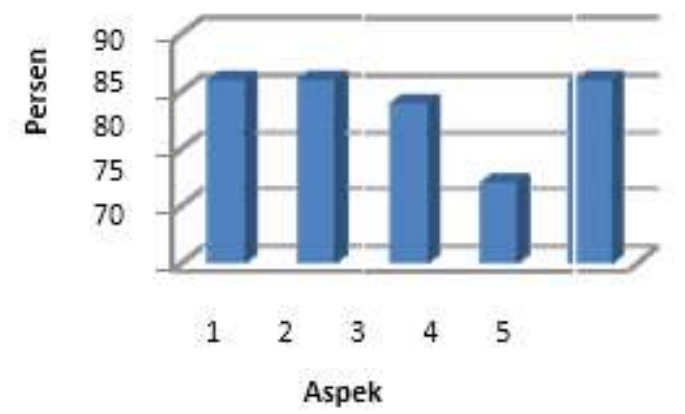

Sumber: Hasil Penelitian, diolah (2016)

Berikut ini analisis hasil angket respon siswa terhadap pembelajaran matematika dengan model pembelajaran kooperatif tipe STAD beserta kriteria di setiap aspeknya

Tabel 3. Analisis Hasil Angket Respon Siswa Terhadap Pembelajaran Matematika

\begin{tabular}{|c|c|c|c|c|c|}
\hline Aspek & 1 & 2 & 3 & 4 & 5 \\
\hline Persentase & $85,94 \%$ & $85,67 \%$ & $83,94 \%$ & $76,57 \%$ & $86,46 \%$ \\
\hline Kriteria & Sangat Baik & Sangat Baik & Sangat Baik & Baik & Sangat Baik \\
\hline
\end{tabular}

Sumber : Hasil Penelitian, diolah (2016)

Keterangan:

1 = Respons siswa terhadap belajarkelompok.

2 = Respons siswa terhadap presentasi hasildiskusi.

3 = Respons siswa terhadap kuis dan penghargaankelompok.

$4=$ Respons siswa dalam membangunpemahaman.

$5=$ Respons siswa terhadap interaksi dalam kegiatan belajar mengajar.

d. Refleksi

Releksi dilakukan oleh peneliti dengan guru setelah pelaksanaan pembelajaran pada siklus II berakhir. Dari hasil refleksi menunjukkan bahwa pelaksanaan pembelajaran pada siklus II telah relatif lebih baik dari pada pelaksanaan pembelajaran siklus I.

Berdasarkan data hasil observasi beberapa kekurangan dalam pelaksanaan tindakan pada siklus I telah diperbaiki, yaitu waktu yang diberikan oleh guru benar-benar dimanfaatkan oleh siswa sehingga tugas selesai dengan tepat waktu. Kerja sama siswa lebih bisa terjalin, ini bisa terlihat saat siswa diskusi kelompok ada siswa yang berusaha mencari cara penyelesaian di buku diktat.

Berdasarkan hasil analisis tes siklus II dapat diketahui bahwa nilai ratarata kelas sebesar 75,56 dan rata-rata persentase nilai tes dalam satu kelas berada pada kriteria tinggi. Dalam analisis hasil tes siklus II menunjukkan bahwa semua indikator pemahaman konsep matematika berada dalam kategori tinggi, sehingga berdasarkan indicator keberhasilan telah tercapai. Selain itu, $87,5 \%$ dari jumlah total siswa dalam satu kelas telah mencapai ketuntasan belajar individu sehingga ketuntasan belajar siswa berdasarkan indikator 
keberhasilan telah tersacapai dan berdasarkan hasil observasi dapat diketahui bahwa pembelajaran matematika dengan menggunakan model pembelajaran kooperatif tipe STAD terlaksana sesuai langkah-langkah yang telah direncanakan. Berdasarkan indikator keberhasilan yang telah ditetapkan, maka indikator keberhasilan telah tercapai sehingga tindakan dihentikan.

\section{Pembahasan}

Pembelajaran matematika melalui model kooperatif tipe STAD ini diawali dengan presentasi kelas oleh guru, yaitu menyampaikan materi dengan jelas dan singkat. Setelah presentasi guru, siswa berkelompok berdiskusi, bekerja sama, dan saling membantu satu sama lain dalam mengintegrasikan pengetahuanpengetahuan baru dengan pengetahuan yang telah dimilikinya. Kelompok diskusi yang digunakan dalam penelitian ini beranggotakan 4-5 orang siswa. Kelompok dibentuk berdasarkan hasil nilai tes awal.

Erman Suherman (2003: 202) menyatakan bahwa ukuran (besar kecilnya) kelompok akan berpengaruh pada kemampuan produktivitas kelompoknya. Ukuran kelompok yang ideal untuk cooperative learning adalah tiga sampai lima orang. Jika suatu kelompok hanya terdiri atas dua orang, maka interaksi antar anggota kelompok akan sangat terbatas dan kelompok itu tidak dapat melakukan diskusi jika satu anggotanya absen. Sebaliknya, jika ukuran kelompok itu terlalu besar maka akan menjadi sangat sulit bagi kelompok itu berfungsi secara efektif. Siswa-siswa yang lebih aktif dalam pembelajaran akan cenderung menguasai dan siswa-siswa yang hanya pendiam akan cenderung menerima saja apa yang diberikan guru. Dalam kelompok yang sangat besar, sulit bagi setiap individu untuk menyampaikan pendapat dan mengkoordinasinya.

Selain itu guru selalu memonitor kinerja siswa dalam kelompok. Guru melakukan hal tersebut agar dapat membantu siswa yang mengalami kesulitan dalam menghubungkan konsep-konsep yang mereka pelajari dengan pengalaman yang mereka miliki. Setelah siswa selesai mendiskusikan LKS yang diberikan, maka kegiatan selanjutnya adalah pembahasan atau presentasi kelas oleh siswa. Siswa menuliskan hasil diskusi kelompok mereka pada papan tulis, dengan menuliskan hasil diskusi kelompok di papan tulis ini maka siswa dapat mengetahui benar atau salah jawaban hasil diskusi mereka, hal ini akan memberi pengetahuan yang lebih kepada siswa.

Pada saat pelaksanaan pembahasan, guru selalu menampung alternatif jawaban yang berbeda yang diperoleh tiap kelompok. Guru juga memerintahkan siswa untuk mencatat hasil diskusi kelas mereka jika jawaban yang diperoleh berbeda dengan jawaban siswa sebelumnya. Saat pembahasan terhadap jawaban dalam presentasi, guru memerintahkan kepada siswa lain untuk mencermati hasil jawaban yang ditulis di papan tulis. Setelah pembahasan selesai, guru mengajak para siswa untuk menyimpulkan materi yang telah disampaikan. Hal ini melatih siswa untuk menganalisis dan menarik kesimpulan dari berbagai pernyataan. Guru juga menghimbau untuk setiap siswa untuk mencatat kesimpulan materi yang disimpulkan oleh guru bersama siswa.

Dari hasil observasi pelaksanaan pembelajaran yang dilakukan, proses pembelajaran dapat berjalan dengan baik. Walaupun ada beberapa yang tidak 
sesuai dengan rencana, karena tidak semua soal pada LKS dapat dipresentasikan oleh siswa seperti yang terjadi pada siklus pertama. Selama kegiatan pembelajaran, terlihat aktivitas siswa lebih dominan dibandingkan dengan guru. Sehingga, proses pembelajaran tidak lagi merupakan pembelajaran yang terpusat pada guru, tetapi siswa menjadi lebih mandiri dalam proses pembelajaran. Belajar dengan cara diskusi kelompok, dimana kelompok terdiri dari anggota dengan tingkat akademis yang heterogen akan memberi kesempatan kepada siswa untuk bekerjasama. Biasanya siswa yang lebih pandai menjadi tempat bertanya teman yang lain.

Berdasar nilai kuis rata-rata nilai siswa terjadi peningkatan dari siklus I ke siklus II. Dalam siklus I, kuis I rata-rata nilai siswa 73,33 dan kuis II rata-rata nilai siswa 74,5, sedangkan untuk siklus II kuis III rata-rata nilai siswa 89,38 dan kuis IV rata-rata nilai siswa 88,79 . Selain itu, dalam lembar rangkuman tim dapat terlihat bahwa ada kelompok yang selalu mendapatkan predikat sebagai tim supers eperti kelompok $\mathrm{A}$ dan $\mathrm{C}$, walaupun masih ada kelompok yang mendapatkan predikat tim sangat baik dan tim baik.

Berdasarkan nilai tes akhir siklus, terjadi peningkatan dari siklus I ke siklus II. Ketuntasan belajar siswa untuk siklus I dan siklus II juga telah melebihi batas ketuntasan belajar minimal siswa kelas VII, yakni sebesar $70 \%$ dari keseluruhan jumlah siswa dalam satu kelas. Untuk lebih jelasnya, data peningkatan hasil belajar siswa berdasarkan tes siklus I dan tes siklus II disajikan pada tabel berikut ini.

Tabel 4. Nilai Rata-Rata Matematika Kelas VII D

Berdasarkan Hasil Tes Siklus I dan Siklus II

\begin{tabular}{|c|c|c|}
\hline & Rata-Rata & Kategori \\
\hline Siklus I & 71,76 & Tinggi \\
\hline Siklus II & 75,56 & Tinggi \\
\hline
\end{tabular}

Sumber : Hasil Penelitian, diolah (2016)

Tabel 5. Ketuntasan Belajar Siswa Kelas VII D

Berdasarkan Hasil Tes Siklus I dan II

\begin{tabular}{|c|c|c|}
\hline & Rata-Rata & Kategori \\
\hline Siklus I & 71,76 & Tinggi \\
\hline Siklus II & 75,56 & Tinggi \\
\hline
\end{tabular}

Sumber : Hasil Penelitian, diolah (2016)

Berdasarkan tes yang dikerjakan siswa secara individu, nampak pula adanya peningkatan pada masing-masing indikator pemahaman konsep matematika siswa dari siklus I ke siklus II. Penghitungan didasarkan atas banyaknya siswa yang menjawab benar untuk setiap butir soal yang menunjukkan masing-masing indikator pemahaman konsep matematika.

Berdasarkan hasil wawancara dengan siswa-siswi kelas VII D, secara umum mengatakan bahwa mereka lebih menyukai metode pembelajaran matematika dengan model pembelajaran kooperatif tipe Student Team Achievement Divisions (STAD). Sebagian besar siswa berpendapat bahwa pembelajaran matematika dengan model pembelajaran kooperatif tipe Student Team Achievement Divisions (STAD) menjadikan mereka lebih mudah dalam memahami materi pelajaran yang sedang dibahas. Pelajaran tidak membosankan dan tidak membuat mereka ngantuk karena siswa dituntut untuk lebih aktif dalam 
diskusi maupun dalam persentasi hasil diskusi. Dalam diskusi kelompok mereka dapat bertukar pikiran dengan teman satu kelompok sehingga materi pelajaran yang sedang diajarkan lebih mudah dipahami dan dimengerti.

Selain hasil wawancara dengan siswa, berdasarkan hasil angket respon siswa menunjukkan bahwa persentase respon siswa terhadap pembelajaran matematika dengan model pembelajaran kooperatif tipe Student Team Achievement Divisions (STAD) adalah $83,98 \%$ dan termasuk ke dalam kategori kriteria sangat baik.

Dalam analisis angket respon siswa dapat dilihat bahwa respon siswa dalam membangun pemahaman termasuk dalam kriteria baik. Walaupun begitu tetapi respon siswa terhadap belajar kelompok, presentasi hasil diskusi, kuis dan penghargaan kelompok, serta respon interaksi dalam kegiatan belajar mengajar termasuk dalam kriteria sangat baik.

Menurut Slavin (2008: 144), fungsi utama dalam tim adalah memastikan bahwa semua anggota tim benar-benar belajar, dan lebih khususnya lagi, adalah untuk mempersiapkan anggotanya untuk mengerjakan kuis dengan baik. Setelah guru menyampaikan materinya, tim berkumpul untuk mempelajari lembar kegiatan atau materi. Pembelajaran melibatkan pembahasan permasalahan bersama, membandingkan jawaban, dan mengoreksi tiap kesalahan pemahaman apabila anggota tim ada yang membuat kesalahan. Menurut Nana Sujana (2004: 79-80), diskusi pada dasarnya adalah tukar menukar informasi, pendapat dan pengalaman dengan maksud untuk mendapat pengertian bersama. Adanya kerjasama dalam kelompok menandakan bahwa semakin banyak ide-ide yang muncul dari setiap siswa.

Ide-ide yang muncul ini tentunya akan semakin memperkaya pengetahuan dan pemahaman siswa. Kemudian, karena tim itulah dapat meningkatkan pemahaman konsep siswa dan akhirnya mencapai prestasi yang diinginkan.

Selain itu menurut Slavin (2008: 11) mengemukakan bahwa jika siswa diberi penghargaan karena melakukan lebih baik dari apa yang mereka lakukan sebelumnya, mereka akan lebih termotivasi untuk berusaha daripada apabila mereka baru diberi penghargaan jika lebih baik dari yang lain, karena penghargaan atas kemajuan untuk meraih sukses bukanlah sesuatu yang terlalu sulit atau terlalu mudah untuk dilakukan siswa. Hal ini dapat terlihat dengan diberikannya poin kemajuan individu, siswa akan tau mereka lebih baik dari pertemuan sebelumnya atau tidak.

Dengan demikian penerapan pembelajaran matematika dengan menggunakan model pembelajaran kooperatif tipe Student Team Achievement Divisions (STAD) pada siswa di SMP Negeri 1 Benjeng khususnya kelas VII D, dapat meningkatkan pemahaman konsep matematika siswa. 


\section{KESIMPULAN DAN SARAN \\ Kesimpulan}

Dari hasil penelitian yang dilakukan dan pembahasan yang telah diuraikan, maka diperoleh kesimpulan bahwa sebagai berikut:

1. Pelaksanaan pembelajaran matematika dengan model pembelajaran kooperatif tipe Student Team Achievement Divisions (STAD) untuk meningkatkan pemahaman konsep matematika adalah sebagai berikut:

a. Guru mengelompokkan siswa menjadi 8 kelompok menurut prosedur STAD, tujuh kelompok beranggotakan 4 orang siswa dan satu kelompok beranggotakan 5 orang siswa.

b. Guru menyampaikan presentasi kelas dengan memberikan materi pelajaran secarasingkat.

c. Siswa berdiskusi dalam kelompok untuk menyelesaikanLKS.

d. Siswa menuliskan hasil diskusi kelompok mereka di papan tulis.

e. Guru bersama siswa melakukan pembahasan alternatif jawaban yang digunakan siswa dalam menjawab pertanyaan.

f. Guru dan siswa menyimpulkan masalah yang telah siswa diskusikan dalam kelompoknya maupun hasil dari presentasi kelas.

g. Dilaksanakan kuis sebanyak 4 kali, kuis dikerjakan secara individu.

h. Menentukan poin kemajuan individu dengan membandingkan skor kuis baru yang diperoleh dengan skor kuis pada pertemuan sebelumnya.

i. Guru memberikan penghargaan kepada kelompok-kelompok yang berprestasi.

2. Pemahaman konsep matematika siswa kelas VII D di SMP Negeri 1 Benjeng mengalami peningkatan setelah dilaksanakan pembelajaran matematika dengan model pembelajaran kooperatif tipe Student Team Achievement Divisions (STAD). Hal ini ditandai dengan nilai rata-rata siswa kelas VII D meningkat dari tes kemampuan awal sebesar 50,67 ke siklus I sebesar 71,76 dan siklus II sebesar 75,56. Peningkatan pemahaman konsep matematika siswa juga terlihat dari peningkatan rata-rata persentase setiap indikator pemahaman konsep matematika dari siklus I ke siklus II yaitu sebagai berikut:

a. Mengklasifikasi obyek-obyek menurut sifat-sifat tertentu (sesuai dengan konsepnya), terjadi peningkatan sebesar 2,58\%.

b. Memberi contoh dan non-contoh dari konsep, ada peningkatan sebesar $4,68 \%$.

c. Menyajikan konsep dalam berbagai bentuk representasi matematis, terjadi peningkatan sebesar $8,98 \%$.

d. Mengembangkan syarat perlu atau syarat cukup suatu konsep, terjadi peningkatan sebesar 3,61\%.

e. Menggunakan, memanfaatkan, dan memilih prosedur atau operasi tertentu, terjadi peningkatan sebesar $3,77 \%$.

f. Mengaplikasikan konsep atau algoritma pemecahan masalah, terjadi peningkatan sebesar $1,47 \%$.

g. Menyatakan ulang sebuah konsep, pada siklus I sudah masuk dalam kategori tinggi. 
h. Selain itu dapat diketahui pula bahwa ketuntasan belajar siswa telah memenuhi batas kriteria kelulusan minimal. Ketuntasan belajar siswa pada siklus I sebesar 72,73\% dan pada siklus II meningkat menjadi 87,5\%.

3. Berdasarkan hasil wawancara siswa menyukai pembelajaran matematika dengan model pembelajaran kooperatif tipe Student Team Achievement Divisions (STAD). Sebagian besar siswa berpendapat bahwa pembelajaran matematika dengan model pembelajaran kooperatif tipe STAD menjadikan mereka lebih mudah dalam memahami materi pelajaran yang sedang dibahas. Pelajaran tidak membosankan dan tidak membuat mereka ngantuk karena siswa dituntut untuk lebih aktif dalam diskusi maupun dalam persentasi hasil diskusi.

4. Berdasarkan data hasil angket respons siswa terhadap model pembelajaran kooperatif tipe Student Team Achievement Divisions (STAD), diperoleh persentase respons siswa sebesar 83,98\% (kriteria sangat baik). Berikut persentase respons siswa pada tiap aspeknya:

a. Respons siswa terhadap belajar kelompok sebesar $85,94 \%$.

b. Respons siswa terhadap presentasi hasil diskusi sebesar $85,67 \%$.

c. Respons siswa terhadap kuis dan penghargaan kelompok $83,94 \%$.

d. Respons siswa dalam membangun pemahaman 76,57\%.

e. Respons siswa terhadap interaksi dalam kegiatan belajar mengajar $86,46 \%$

\section{Saran}

Berdasarkan hasil penelitian yang dilakukan dan pembahasan, selama pelaksanaaan penelitian dengan model pembelajaran kooperatif tipe Student Achievement Divisions (STAD) yang telah dilakukan, peneliti memberikan masukan atau saran yang perlu dipertimbangkan oleh berbagai pihak berkaitan dengan penerapan model pembelajaran STAD sebagai upaya meningkatkan pemahaman konsep matematika pada siswa kelas VII D SMP Negeri 1 Benjeng, yaitu:

1. Kepada pihak sekolah, diharapkan agar metode belajar ini dapat menjadi metode alternatif yang digunakan di SMP Negeri 1 Benjeng dan dapat dilaksanakan secara bergantian dengan model pembelajaran yang lain. Karena penerapan model pembelajaran kooperatif tipe Student Achievement Divisions (STAD) dapat meningkatkan pemahaman konsep matematika siswa.

2. Kepada peneliti lain dapat melakukan penelitian lebih lanjut menggunakan model pembelajaran STAD dengan mencakup aspek selain pemahaman konsep dan mengaplikasikannya pada materi pembelajaran yang berbeda atau pada mata pelajaran selain matematika.

\section{DAFTAR PUSTAKA}

Anonim. (Tanpa tahun). Pengertian Belajar dan Perubahan Perilaku dalam Belajar.http://www.scribd.com/doc/6439508/Pengertian-Belajar

Lintang?autodown=pdf Diakses pada tanggal 3 Juli 2016

Anas Sudijono. 1996. Pengantar Evaluasi Pendidikan. Jakarta : PT Raja Grafindo Persada

Erman Suherman. 2003. Strategi Pengajaran Matematika Kontemporer. Bandung: JICA 
I Made Suriant. (Tanpa tahun). Penerapan Model Pembelajaran Kooperatif Type STAD dengan Media VCD untuk Meningkatkan Prestasi Belajar Matematika Siswa Kelas IX B SMP Negeri 1 Banjarangkan tahun 2008/2009. http://disdikklungkung.net/content/view/73/46/. Diakses pada tanggal 20 Juli 2016

Nana Sudjana. 2002. Penilaian Hasil Proses Belajar Mengajar. Bandung: Remaja Rodaskarya

Robert E. Slavin. 2008. COOPERATIVE LEARNING Teori Riset dan Praktik. (terjemahan). Bandung: Nusa Media. Buku asli diterbitkan (London: Allymand Bacon, 2005).

Rochiati Wiriaatmadja. 2009. Metode Penelitian Tindakan Kelas. Bandung : Remaja Rosdakarya.

Suharsimi Arikunto. 1986. Pengelolaan Kelas dan Siswa Sebuah Pendekatan Evaluatif. Jakarta : Rajawali

Suharsimi Arikunto, Suhardjono, \& Supardi. 2006. Penelitian Tindakan Kelas. Jakarta: Bumi Aksara. 